\title{
PERBEDAAN KADAR TRIGLISERIDA ANTARA ANGGOTA SENAM BODY $L A N G U A G E$ DENGAN ANGGOTA SENAM HIGH IMPACT SETELAH PEMBERIAN ASUPAN MAKANAN YANG SEBELUMNYA MELAKUKAN SENAM BODY LANGUAGE DAN SENAM HIGH IMPACT
}

\author{
Dewi Kurniawati ${ }^{1,2}$, Ambrosius Purba ${ }^{3}$, Nur Siti Fatimah ${ }^{3}$ \\ ${ }^{1}$ Program Studi Ilmu Kedokteran Dasar, Fakultas Kedokteran, Universitas Padjadjaran \\ ${ }^{2}$ Fakultas Pendidikan Olahraga Dan Kesehatan, Universitas Pendidikan Indonesia \\ ${ }^{3}$ Departemen Anatomi Fisiologi dan Biologi Sel, Fakultas Kedokteran, Universitas Padjadjaran
}

\begin{abstract}
The majority of studies has found that aerobic exercise can reduce the increment of triglyceride postprandial in plasma. Therefore, the author is doing this research to know the difference of triglyceride concentration in plasma between group who joint high impact exercise and group who joint body language exercise after given the same amount and dietary composition which had done high impact and body language exercise before. Twenty men (19-39 years old) did high impact or body language exercise for 1 hour. Two hours later, they were given dietary composition with carbohydrate $60 \%$ and fat $25 \%$. Then the triglyceride postprandial concentrations were measured 3, 5, and 6 hours after the given dietary food. The result showed that the trygliceride concentration of high impact group was higher than body language group 3 hours after given dietary food $(122.167 \pm 17.11627 \mathrm{vs} 111.67 \pm 7.86554 \mathrm{mg} / \mathrm{dL})$ and there were no difference between high impact and body language group 5 hours (96.167 \pm 7.25029 vs $94.0 \pm$ $16.66133 \mathrm{mg} / \mathrm{dL})$ and 6 hours after given dietary food $(77.5 \pm 8.8261 \mathrm{vs} 78.167 \pm 14.27469$ $\mathrm{mg} / \mathrm{dL}$ ).In conclusion, the trygliceride concentration of high impact group was higher than body language group 3 hours after given the same amount and dietary composition. But, there were no difference between trygliceride concentration of body language group and high impact group 5 and 6 hours after given the same amount and dietary composition which had done high impact and body language exercise before.
\end{abstract}

Keywords: body language exercise, high impact exercise, triglyceride postprandial

Korespondensi: Dewi Kurniawati, E-mail: kurniawatidewi113@gmail.com , Departemen Anatomi, Fisiologi, dan Biologi Sel, Fakultas Kedokteran Universitas Padjadjaran. Jalan Raya Jatinangor Km 21, Sumedang, Jawa Barat, Indonesia. 


\section{PENDAHULUAN}

Dislipidemia merupakan salah satu faktor yang mempengaruhi terjadinya penyakit jantung koroner. Tanda dari Dislipidemia, yaitu: hiperkolesterolemia, hipertrigliseridemia, kadar Low-density Lipoprotein ( LDL) yang tinggi dan kadar High-density Lipoprotein (HDL) yang rendah (Hultman, HarrisdanSpriet, 1999). Penelitian sebelumnya yang dilakukan oleh Rapp dkk. (1994) menunjukkan adanya lipoprotein yang kaya akan trigliserida yang terdeposit pada plak aterosklerosis (Karpe, 1997). Oleh karena itu, saat ini diduga bahwa kadar trigliserida postprandial berhubungan dengan terjadinya penyakit jantung koroner.

Kadar trigliserida postprandial dipengaruhi oleh berbagai faktor antara lain olahraga dan asupan makanan. Penurunan kadar trigliserida postprandial saat berolahraga dipengaruhi oleh peningkatan aktivitas enzim Lipoprotein Lipase (LPL) yang dirangsang saat berolahraga (Zhang, Thomas, Ball, 1998). Enzim LPL merupakan enzim yang menghidrolisis trigliserida dalam plasma. Seip dkk. (1997) menemukan bahwa olahraga satu kali dengan intensitas sedang selama 80-95 menit menunjukkan peningkatan aktivitas enzim LPL. Jumlah enzim LPL tidak meningkat segera setelah olahraga, namun meningkat sebanyak 53\% setelah 4 jam, $93 \%$ setelah 8 jam, dan baru menurun setelah 20 jam. Hal ini menunjukkan bahwa peningkatan maksimum aktifitas LPL terjadi dalam 8-20 jam setelah berolahraga (HardmandanHerd, 1998).

Aktivitas LPL juga dipengaruhi oleh kadar insulin. Insulin menurunkan aktivitas LPL pada otot yang tidak berolahraga, namun tidak memiliki pengaruh pada otot yang berolahraga. Pada penelitian yang dilakukan oleh Kiens (1989), didapatkan bahwa pada pemberian insulin, aktivitas LPL pada otot yang berolahraga tidak terpengaruh, sedangkan aktivitas LPL pada otot yang tidak berolahraga menurun (Hardman dan Herd, 1998). Insulin juga menyebabkan inhibisi lipolisis simpanan trigliserida pada sel adiposa oleh Hormone Sensitive Lipase (HSL) (Watford dan Goodridge, 2000). Namun pada keadaan setelah berolahraga, di mana terjadi peningkatan katekolamin, aktivitas HSL meningkat. Akibatnya penyediaan asam lemak ke dalam plasma untuk oksidasi asam lemak meningkat (Kiens, 2006).

Penelitian yang dilakukan Ziogas (1997) menyatakan bahwa olahraga senamaerobik mengurangi peningkatan kadar trigliserida plasma setelah makan makanan tinggi lemak (Zhang, Thomas, Ball, 1998).Adapun olahraga senam aerobik memiliki beberapa variasi yaitu : Low Impact, High Impact, dan Step. Olahraga senam aerobik High Impact merupakan gerakan aerobik yang terdapat gerakan-gerakan dengan kedua kaki tidak menyentuh tanah. Olahraga ini menggunakan unsur gerakan-gerakan melompat. Olahraga senam Body Language, merupakan pengembangan dari senam aerobik Low Impact, adalah salah satu bentuk olah tubuh yang memadukan gerak tari dan teknik pernapasan asal Cina. Gerakan-gerakannya halus, sederhana, bahkan cenderung lamban tanpa unsur lompatan.

Sebagian besar penelitian yang telah dilakukan untuk menentukan efek olahraga terhadap kadar trigliserida postprandial, menggunakan asupan makanan tinggi lemak ( $>60 \%$ total energi). Hal ini memperbesar efek penurunan kadar trigeliserida postprandial akibat olahraga (Petridoudkk., 2004). Namun penelitian yang dilakukan oleh Koutsari dan Hardman (2001), menemukan bahwa olahraga yang dilakukan secara rutin dapat menghambat peningkatan kadar trigliserida postprandial setelah pemberian asupan makanan tinggi karbohidrat. Penelitian lain yang dilakukan oleh Kolifa, Petridou, dan Mougios (2004) menemukan bahwa olahraga yang dilakukan 14 jam sebelum pemberian asupan makanan tinggi karbohidrat, menurunkan kadar trigliserida postprandial (Kolifa, Petridou, dan Mougios, 2004). Adapun komposisi makanan masyarakat Indonesia yang direkomendasikan oleh Pedoman Umum Gizi Seimbang (PUGS) tahun 2002, yang disesuaikan dengan hasil Widyakarya Nasional Pangan dan Gizi VI tahun 1998, yaitu untuk karbohidrat sebesar $60 \%$ dari kebutuhan energi dan lemak tidak melebihi $25 \%$ dari kebutuhan energi (Bina Kesehatan Masyarakat, 2002).

Pengaruh jenis olahraga aerobik pada kadar trigliserida plasma setelah pemberian asupan makanan sesuai dengan rekomendasi PUGS (2002) belum diketahui. Dari latar belakang tersebut, penulis melakukan penelitian tentang Perbedaan Kadar Trigliserida Antara Anggota Senam Body Language dengan Anggota Senam High Impact Setelah Pemberian Asupan Makanan yang Sebelumnya Melakukan Senam Body Language dan Senam High Impact.

Pada penelitian ini subjek akan diberikan asupan makanan sesuai rekomendasi Pedoman Umum Gizi Seimbang (PUGS) tahun 2002, yaitu untuk karbohidrat sebesar $60 \%$ dari kebutuhan energi dan lemak tidak melebihi $25 \%$ dari kebutuhan energi (Bina Kesehatan Masyarakat, 2002).

\section{METODE}

Subjek

Subjek penelitian dipilih secara acak sebanyak 20 orang pria berdasarkan perhitungan besaran 
sampel. Kemudian sampel dibagi dua kelompok secara random. Adapun kriteria inklusi: pria, 19-39 tahun, IMT normal, normotriasilgliserolemia, tekanan sistolik $<120 \mathrm{mmHg}$ dan diastolik $<80$ $\mathrm{mmHg}$ dan kriteria eksklusi memiliki penyakit jantung dan gangguan metabolisme, menggunakan obat-obatan yang mempengaruhi metabolisme lemak dan karbohidrat, merokok, dan olahragawan.

\section{Desain Penelitian}

Desain penelitian ini menggunakan rancangan eksperimental tanpa matching. Subjek penelitian dibagi ke dalam kelompok senam Body Language dan kelompok senam High Impact secara random. Subjek penelitian datang ke tempat penelitian pukul 07.00 setelah berpuasa semalam selama 10 jam. Subjek pada kedua kelompok dilakukan pengukuran kadar trigliserida (baseline). Setelah dilakukan pengukuran trigli-serida, kelompok A melakukan olahraga aerobik High Impact selama 1 jam dan kelompok B melakukan olahraga senam Body Language selama 1 jam. Dua jam setelah olahraga selesai, subjek diberi makanan dengan komposisi karbohidrat 60\%, lemak 25\%. Setelah 3 jam, 5 jam, dan 6 jam pemberian makanan, subjek diukur kembali kadar trigliserida postprandial. Selama pengukuran tersebut, subjek hanya diperbolehkan minum air mineral.

\section{Bahan dan Alat Penelitian}

Bahan untuk pengukuran kadar trigliserida post-prandial menggunakan etilendiamintetraasetat (EDTA). Alat yang digunakan untuk pengukuran kadar trigliserida post-prandial adalah tabung sampel darah, jarum suntik, pipet, alat sentrifugasi.Alat-alat lainnya yang digunakan dalam penelitian adalah stop watch, timbangan badan, meteran, stetoskop, tensimeter.

\section{Analisis Data}

Pada data hasil pengukuran kadar trigliserida (mg/dL) 3jam, 5jam, dan 6 jam setelah pemberian asupan makanan, dilakukan uji normalitas dengan Kolmogorov-Smirnov untuk mengetahui rerata data sampel berdistribusi normal atau tidak normal. Bila data berdistribusi normal, dilakukan uji-t tidak berpasangan untuk mengetahui perbedaan kadar trigliserida postprandial pada tiap kelompok. Bila data tidak berdistribusi normal, maka dilakukan uji non parametrik dengan uji Mann Whitney.

\section{Tempat dan Waktu Penelitian}

Penelitian dilakukan pada bulan Oktober 2008, di Pusat Kebugaran Universitas Padjadjaran Bandung.

\section{HASIL}

Karakteristik fisik fisiologis berupa usia (tahun), berat badan $(\mathrm{kg})$, tinggi badan $(\mathrm{cm})$, indeks massa tubuh $(\mathrm{kg} / \mathrm{m} 2)$, kadar trigliserida baseline (mg/dL), asupan kalori per hari berdasarkan Food Recall (kal), presentase asupan karbohidrat per hari $(\%)$, presentase asupan lemak per hari (\%) dan aktifitas fisik pada kelompok subjek yang mengikuti latihan senam Body Language dan pada kelompok yang mengikuti latihan senam High Impact tercantum pada tabel 1 .

Hasil pengukuran kadar trigliserida antara anggota senam Body Language dan anggota senam High Impact 3, 5, dan 6 jam setelah pemberian asupan makanan dengan jumlah dan komposisi sama yang sebelumnya melakukan senam Body Language dan senam High Impact tercantum pada tabel 2. Untuk mengetahui perbedaan kadar trigliserida antara anggota senam Body Language dan anggota senam High Impact tersebut dilakukan uji-t tidak berpasangan.

Hasil dari uji- $t$ tidak berpasangan pada tabel 2 menunjukkan bahwa terdapat perbedaan kadar trigliserida antara anggota senam Body Language dan anggota senam High Impact 3 jam setelah pemberian asupan makanan dengan jumlah dan komposisi sama yang sebelumnya melakukan senam

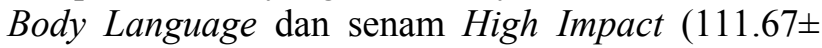
7.86554 vs $122.8333 \pm 16.3758 \mathrm{mg} / \mathrm{dL}$ ), namun tidak terdapat perbedaan kadar trigliserida antara anggota senam Body Language dan anggota senam High Impact 5 jam (96.167 \pm 7.25029 vs $95.0 \pm$ $15.8871 \mathrm{mg} / \mathrm{dL}$ ) dan 6 jam setelah pemberian asupan makanan dengan jumlah dan komposisi sama yang sebelumnya melakukan senam Body Language dan senam High Impact $(77.5 \pm 8.8261$ vs $79.6667 \pm$ $13.83715 \mathrm{mg} / \mathrm{dL})$. 
Tabel 1 Karakteristik fisik fisiologis subjek penelitian

\begin{tabular}{|c|c|c|}
\hline & $\begin{array}{l}\text { Kelompok A } \\
\text { (senam Body } \\
\text { Language) } \\
\quad x \pm \text { SD }\end{array}$ & $\begin{array}{c}\text { Kelompok A } \\
\text { (senam High Impact) } \\
\\
\mathbf{x} \pm \text { SD }\end{array}$ \\
\hline Umur (tahun) & $19.6667 \pm 0.8165$ & $20.00 \pm 0.63246$ \\
\hline Berat Badan (BB) (kg) & $62.00 \pm 7.9465$ & $60.6667 \pm 6.80196$ \\
\hline Tinggi Badan (TB) $(\mathrm{cm})$ & $167.8333 \pm 5.91326$ & $169.8333 \pm 8.20772$ \\
\hline Indeks Massa Tubuh (IMT) $\left(\mathrm{kg} / \mathrm{m}^{2}\right)$ & $21.95 \pm 1.91485$ & $20.9883 \pm 1.21177$ \\
\hline Kadar Trigliserida (TG) baseline (mg/dL) & $79.1667 \pm 19.61037$ & $81.8333 \pm 5.23132$ \\
\hline $\begin{array}{l}\text { Asupan energi per hari berdasarkan Food Recall (FR) } \\
\text { (kcal) }\end{array}$ & $\begin{array}{c}2657.6717 \pm \\
442.01085\end{array}$ & $\begin{array}{c}2287.5383 \pm \\
357.64284\end{array}$ \\
\hline Presentasi asupan karbohidrat (KH) per hari (\%) & $65.2217 \pm 5.73292$ & $70.7217 \pm 9.37275$ \\
\hline Presentasi asupan lemak per hari $(\%)$ & $21.445 \pm 5.25007$ & $17.2217 \pm 8.29882$ \\
\hline Indeks aktifitas fisik & $9.0233 \pm 1.24699$ & $9.2517 \pm 1.48366$ \\
\hline
\end{tabular}

Tabel 2 Hasil pengukuran dan uji-t tidak berpasangan

\begin{tabular}{ccccc}
\hline & \multicolumn{2}{c}{ Rata-rata dan Simpangan baku } & \multirow{2}{*}{ T } & P \\
\hline TG 3jam & Body Language & High Impact & & 0.0875 \\
TG 5jam & $911.67 \pm 7.86554$ & $122.8333 \pm 16.3758$ & -1.506 & 0.4375 \\
TG 6jam & $96.167 \pm 7.25029$ & $95.0 \pm 15.8871$ & 0.164 & 0.377 \\
\hline Keterangan: & $\mathrm{p} \leq 0.1$ : signifikan (bermakna) & & -0.323 & \\
& pada taraf kekeliruan 10\% & & & \\
& $\mathrm{p} \leq 0.05:$ signifikan (bermakna) & & & \\
& pada taraf kekeliruan 5\% & & & \\
& $\mathrm{p}>0.05:$ tidak bermakna & & & \\
& TG: Kadar Trigliserida & &
\end{tabular}

\section{DISKUSI}

Hasil penelitian menunjukkan bahwa kadar trigliserida anggota senam High Impact lebih tinggi dari anggota senam Body Language 3 jam setelah pemberian asupan makanan dengan jumlah dan komposisi sama. Pada umumnya, olahraga Body Language dilakukan pada intensitas sedang. Total penggunaan energi yang berasal dari oksidasi lemak pada olahraga intensitas sedang paling tinggi bila dibandingkan dengan olahraga intensitas rendah dan tinggi. Olahraga High Impact, di mana pada umumnya dilakukan pada intensitas yang tinggi, menggunakan glukosa sebagai sumber energi. Keadaan tinggi glukosa dalam plasma akan menyebabkan peningkatan malonyl-coA yang merupakan inhibitor dari CPT1. Akibatnya proses transportasi asam lemak ke dalam mitokondria terhambat, yang pada akhirnya menghambat oksidasi lemak. Sidossis (2001) juga menyatakan bahwa pada olahraga intensitas tinggi $(>65 \%$ $\mathrm{VO}_{2}$ max), glukosa menjadi sumber bahan bakar energi utama untuk oksidasi, sedangkan pada olahraga intensitas sedang $\left(30-65 \% \mathrm{VO}_{2} \max \right)$, peran glukosa sebagai sumber energi menurun dan oksidasi dari asam lemak meningkat (Sidossis, 2001).

Namun hasil pengukuran pada 5 jam setelah pemberian asupan makanan menunjukkan bahwa tidak terdapat perbedaan kadar trigliserida anggota senam High Impact dananggota senam Body Language. Analisis mengenai tidak adanya perbedaan tersebut dapat ditinjau dari berbagai hal. Penggunaan asam lemak sebagai energi pada olahraga melalui beberapa proses. Proses yang pertama yaitu penyediaan asam lemak sebagai sumber energi. Asam lemak sebagai sumber energi berasal dari VLDL, simpanan triasilgliserol dalam sel adiposa dan simpanan triasilgliserol dalam sel otot. Berbagai penelitian telah menyatakan bahwa pada olahraga intensitas tinggi $\left(>65 \% \mathrm{VO}_{2} \max \right)$, glukosa menjadi sumber bahan bakar energi utama untuk oksidasi, sedangkan pada olahraga intensitas sedang (30-65\% $\mathrm{VO}_{2} \max$ ), peran glukosa sebagai sumber energi menurun dan oksidasi dari asam lemak meningkat. Namun terdapat penelitian yang dilakukan oleh Romijn, Coyle dan Sidossis (1993), 
ditemukan bahwa tidak terdapat perbedaan indeks lipolisis pada olahraga intensitas sedang $(65 \%$ $\begin{array}{lllll}\left.\mathrm{VO}_{2} \mathrm{max}\right) & \text { dan intesitas tinggi }(85 \% & \mathrm{VO}_{2} \max \end{array}$ (Horowitz dan Klein, 2000). Kiens (2006) juga menyatakan bahwa kecepatan lipolisis dipengaruhi oleh aktifitas fisik seseorang (trained/ untrained) dan pola diet, bukan oleh intensitas dari olahraga. Pada individu dengan aktifitas yang tinggi atau terlatih, terjadi peningkatan mikro-sirkulasi pada area serabut otot, sehingga semakin luas binding site untuk LPL. Peningkatan mikrosirkulasi tersebut juga menyebabkan peningkatan perfusi jaringan dan penurunan kecepatan difusi yang menyebabkan waktu kontak yang lebih lama antara VLDL dan LPL. Akibatnya aktifitas LPL meningkat (Kiens, 2006). Adapun subjek pada kedua kelompok senam memiliki tingkat aktifitas yang sama tinggi, sehingga kedua kelompok memiliki aktifitas LPL yang sama. Selain itu aktifitas LPL mencapai aktifitas maksimum pada 8-20 jam setelah olahraga. Olehkarena itu, tidak terdapatnya perbedaan kadar trigliserida anggota senam High Impact dananggota senam Body Language lebih jelas tampak sekitar 8 jam setelah olahraga (pada penelitian ini $5-6$ jam setelah pemberian asupan makanan).

Proses berikutnya meliputi transportasi asam lemak dari sirkulasi darah ke dalam sitosol. Proses transportasi ini melibatkan aktifitas protein yang mengikat lemak, yaitu plasma membrane-bound fatty acid binding protein $\left(\mathrm{FABP}_{\mathrm{pm}}\right)$, fatty acid translocase (FAT/CD36) dan fatty acid transport protein (FATP). Asam lemak yang masuk ke dalam sitosol akan mengalami oksidasi dalam mitokondria atau mengalami resintesis menjadi trigliserida. Adapun aktivitas dari FAT/CD36, salah satu protein yang mengikat lemak, tidak dipengaruhi oleh intensitas dari olahraga. Kiens, Roemen dan Van der Vusse (1999) menemukan bahwa pada intensitas $\begin{array}{lllll}\text { olahraga yang meningkat dari } & 65 \% & \mathrm{VO}_{2} \max \end{array}$ menjadi $90 \% \mathrm{VO}_{2} \max$, di mana oksidasi asam lemak menurun, kadar asam lemak dalam sel otot tetap meningkat dengan disertai kadar asam lemak yang menurun pada plasma (Kiens, 2006). Hal ini menunjukkan bahwa transportasi asam lemak ke dalam sitosol tidak dipengaruhi oleh intensitas dari olahraga.

Adapun FAT/CD36, salah satu protein yang mengikat lemak, ditemukan lebih banyak terdapatpada serabut otot tipe 1 (slow twitch) dibandingkan tipe 2 (fast twitch) (Kiens, 2006). Pada penelitian ini, tidak diketahui variasi dari subjek penelitian mengenai jumlah serabut otot yang mendominasi pada tiap subjek penelitian.

Proses yang terjadi selanjutnya adalah proses metabolisme asam lemak dalam mitokondria. Pada olahraga aerobik High Impact, metabolisme yang terjadi merupakan metabolisme aerobik yang menggunakan oksigen untuk menghasilkan energi. Adapun sumber bahan bakar utama untuk metabolisme aerob berasal dari glukosa (yang berasal dari hepar), simpanan glikogen dalam otot serta asam lemak bebas (yang berasal dari simpanan trigliserida pada otot).

Pada umumnya sebagian besar aktivitas dari olahraga aerobik High Impact dilakukan pada intensitas yang tinggi, dengan sumber energi utama berasal dari glukosa. Namun pada prolonged exercise, ketika simpanan glikogen otot berkurang, oksidasi lemak berperan dalam mempertahankan penyediaan energi dan mencegah terjadinya hipoglikemia. Selain itu Romijn (1995) menyatakan bahwa sulit untuk mempertahankan olahraga tetap pada intensitas $85 \% \mathrm{VO}_{2}$ max pada durasi lebih dari 30 menit (Horowitz dan Klein, 2000).

Pada olahraga intensitas tinggi, dengan $75 \%$ energi yang berasal dari karbohidrat dengan 80\%nya berasal dari simpanan glikogen otot, terjadi deplesi simpanan glikogen otot (Wilsondan Wilson, 2005).Oleh karena itu, pada keadaan di mana oksidasi karbohidrat menurun, olahraga akan meningkatkan aktifitas AMP-activated protein kinase (AMPK) yang menyebabkan inaktifasi acetyl-CoA carboxylase (ACC), yang pada akhirnya menurunkan pembentukan malonyl CoA (Kiens, 2006). Penurunan malonyl CoA akan menurunkan inhibisi CPT 1 yang pada akhirnya meningkatkan oksidasi lemak (Sidossis, 2001).

Pada penelitian yang dilakukan oleh Gill, Herd, Tsetsonis dan Hardman (2002) ditemukan bahwa energy expenditure memiliki korelasi yang signifikan dengan kadar trigliserida postprandial (Gill dkk., 2005). Adapun energi yang digunakan pada olahraga meningkat sebanding dengan peningkatan intensitas olahraga. Pada penelitian ini tidak dilakukan pengukuran besar energi yang digunakan dari tiap olahraga yang dilakukan. Diperkirakan bahwa pada olahraga High Impact, di mana intensitas olahraga lebih tinggi dibandingkan olahraga Body Language, menggunakan energi yang lebih besar pada durasi olahraga yang sama. Hal ini menyebabkan pemakaian sumber energi yang lebih besar yang menyebabkan penurunan kadar trigliserida postprandial.

Hasil pengukuran pada 6 jam setelah pemberian asupan makanan menunjukkan bahwa tidak terdapat perbedaan kadar trigliserida anggota senam High Impact dananggota senam Body Language. Pada pemeriksaan kadar trigliserida 6 jam setelah pemberian asupan makanan, kadar lipid telah mengalami penurunan mendekati angka baseline. Gropper (2005) menyatakan bahwa kadar lipid mencapai puncaknya pada plasma biasanya 
dalam 30 menit sampai 3 jam setelah makan, dan kembali mendekati normal dalam 5-6 jam (Gropper, Smith, Groff, 2005).

Oleh karena itu meskipun aktivitas LPL masih berlangsung, tidak terdapat perbedaan kadar trigliserida pada kedua kelompok. Hasil penelitian sejalan dengan analisis di mana tidak terdapat perbedaan kadar trigliserida anggota senam High Impact dananggota senam Body Language 6 jam setelah pemberian asupan makanan dengan jumlah dan komposisi sama.

\section{KESIMPULAN}

Penelitian ini menyimpulkan bahwa kadar trigliserida anggota senam High Impact lebih tinggi dari anggota senam Body Language 3 jam setelah pemberian asupan makanan, namun tidak terdapat perbedaan kadar trigliserida 5 jam dan 6 jam setelah pemberian asupan makanan dengan jumlah dan komposisi sama yang sebelumnya melakukan senam Body Language dan senam High Impact.

\section{DAFTAR PUSTAKA}

1. Bina Kesehatan Masyarakat. 2002. Pedoman Umum Gizi Seimbang. Jakarta: Bina Kesehatan Masyarakat.

2. Gill JMR, Herd SL, Tsetsonis NV, Hardman AE. 2002. Are the reductions in triacylglycerol and insulin levels after exercise related?. Clin Sci. 102 : 223-231.

3. Gropper SS, Smith JL, Groff JL, editors. 2005. Advanced Nutrition and Human Metabolism. $4^{\text {th }} \mathrm{ed}$. Belmont : Thomson Wadsworth.

4. Hardman AE, Herd SL. 1998. Exercise and Postprandial Lipid Metabolism. Proceedings of the Nutri Soc. 57: 63-72.

5. Horowitz JF, Klein S. 2000. Lipid Metabolism during Exercise. Am J Clin Nutr. 72: 558S-63S.

6. Hultman E, Harris RC, Spriet LL. 1999. Diet in Work and Exercise Performance. In Shils ME, Olson JA, Shine M, Rose AC, editors. Modern Mutrition in Health and Disease. Maryland : Lippincott Williams \& Wilkins. p. 761-782.

7. Karpe F. 1997. Postprandial Lipid Metabolism in relation to Coronary Heart Disease. Proceedings of the Nutri Soc. 56: 671-678.

8. Kiens B. 2006. Skeletal Muscle Lipid Metabolism in Exercise and Insulin Resistance. Physiol Rev. 86 : 205-243.

9. Kolifa M, Petridou A, Mougios V. 2004. Effect of Prior Exercise on Lipemia after a Meal of Moderate Fat Content. European J of Clin Nutri. 58 : 13271335.

10. Petridou AL, Gerkos N, Kolifa M, Nikolaidis MG, Simos D, Mougios V. 2004. Effect of Exercise Performed Immediately before a Meal of Moderate Fat Content on Postprandial Lipaemia. British Jof Nutri. $91: 683-687$.

11. Sidossis LS. 2001. Regulation of Lipid Metabolism during Exercise. In Simopoulos AP, Pavlou KN,editors. Nutrition and Fitness : Metabolic Studies in Health and Disease. Basel : Karger. p. 44-54.

12. Watford M, Goodridge AG. 2000. Regulation of Fuel Utilization. In Stipanuk MH,editor. Biochemical and Physiological Aspectsof Human Nutrition. New York : W.B. Saunders Company. p. 384-410.

13. Zhang JQ, Thomas TR, Ball SD. 1998. Effect of Exercise Timing on Postprandial Lipemia and HDL Cholesterol Subfractions. J Appl Physiol. 85 : 15161522 . 